\title{
Ankylosing spondylitis and HLA-B27: restriction fragment length polymorphism and sequencing of an HLA-B27 allele from a patient with ankylosing spondylitis
}

Colleen M Higgins, Torben Lund, Michael E Shipley, Alan Ebringer, Maria Sadowska-Wroblewska," Roger K Craig

\begin{abstract}
Two groups of patients with ankylosing spondylitis (AS) from England and Poland were examined for restriction fragment length polymorphisms (RFLPs) associated with the disease. No preferential association was found between the $9.2 \mathrm{~kb}$ Pvull fragment in HLA-B27 positive patients with AS compared with HLA-B27 healthy subjects as had been previously reported. In the English group, however, a 14 kb Pvull fragment was more common in HLA-B27 positive subjects with AS than in normal controls. Also 4.6 and 3.7 kb Pvull fragments were more prevalent in subjects without AS than in the group with AS, but these results were confined to the English group. Furthermore, the sequence of an HLA-B $\star 2705$ gene isolated from a patient with AS was examined, and no significant differences were found compared with the sequence isolated from a healthy subject. There do not seem to be significant genetic differences in the coding or in the regulatory region in HLA-B27 alleles, in subjects with or without AS.
\end{abstract}

(Ann Rheum Dis 1992; 51: 855-862)
Ankylosing spondylitis (AS) is an inflammatory disease affecting the sacroiliac joints, spine, and peripheral joints. Patients with reactive arthritis associated with HLA-B27 often have a history of antecedent infection with microorganisms such as salmonella, shigella, and yersinia, ${ }^{1}$ whereas in patients with AS klebsiella has been implicated as a possible cause. ${ }^{23} \mathrm{~A}$ strong association exists between AS and the major histocompatibility complex (MHC) class I antigen HLA-B27, ${ }^{45}$ with over $90 \%$ of patients with AS carrying this HLA antigen compared with a prevalence of HLA-B27 of less than $8 \%$ in the white population. The relative risk for subjects carrying HLA-B27 has been shown to be greater than $70 .{ }^{6}$ HLA-B27 is present in 50\% of American black subjects with AS, whereas only $2 \%$ of the American black population have the HLA-B27 allele. ${ }^{7}$

Despite the close association between AS and HLA-B27 the mechanism underlying it remains unclear. It has been suggested that HLA-B27 is linked directly to the pathology of AS through the mechanism of molecular mimicry by means of immunological cross reactivity between antigens on the associated bacteria and the
HLA-B27 molecule. ${ }^{\gamma}$ Alternatively, it may not be HLA-B27 itself which plays a part in the disease development but a gene in linkage disequilibrium with HLA-B27. There is reported to be no difference between the amino acid sequence of the extracellular domains of HLAB27 antigen in patients with AS and in nondiseased subjects. ${ }^{9}$

Restriction fragment length polymorphism (RFLP) analysis has been used to examine the possibility of linking a particular allelic form of HLA-B27 with AS. Using an HLA-B7 cDNA probe, McDaniel et al showed that a polymorphic 9.2 kb PvuII DNA fragment was present in $72.9 \%$ of HLA-B27 positive patients with AS but in only $22 \%$ of HLA-B27 positive normal white subjects from Alabama, USA. ${ }^{10}$ Segregation studies in families showed that the $9.2 \mathrm{~kb}$ PvuII polymorphic DNA fragment is not a polymorphism of the HLA-B27 allele. A number of more recent RFLP studies have failed to confirm an association between the $9 \cdot 2 \mathrm{~kb}$ PvuII fragment and AS. ${ }^{11-13}$

We report here our studies of two groups of European patients with AS, usually genetically more homogeneous than American patients, who were investigated to determine a possible association between RFLPs and AS.

\section{Materials and methods}

SUBJECTS

Thirty four unrelated English patients with AS (seven women, 27 men), all with classical AS according to the New York criteria, ${ }^{14}$ were studied. Thirty two of the 34 patients were white. Thirty two patients had peripheral joint disease and 14 had had uveitis. Only one HLAB27 negative patient was included, who had peripheral joint disease but not uveitis. Thirty two healthy English subjects with no previous history of AS in the family, including seven who were positive for HLA-B27, served as controls.

Twenty Polish white patients with AS were also studied, of whom 10 had peripheral joint disease. The incidence of uveitis among these patients was not known. Thirteen healthy, white Polish subjects, of whom seven were HLA-B27 positive without any history of arthritis or spondylitis, served as controls.

PROBES

Full length HLA-B27 cDNA probe $\mathrm{pB} 1^{15}$ was kindly provided by Dr E Weiss. HLA-B27 5' 
and $3^{\prime}$ cDNA probes were derived from $\mathrm{pB} 1$. The $5^{\prime}$ cDNA probe was a 415 bp PstI-PvuII fragment containing the sequences encoded in the leader sequence, the presequence, the $\alpha 1$ domain, and $194 \mathrm{bp}$ of the $\alpha 2$ domain. The $3^{\prime}$ cDNA probe consisted of the 550 bp PvuII-PstI fragment containing the $3^{\prime}$ untranslated region of $\mathrm{pB} 1 \mathrm{cDNA}$. The HLA-B27 3' flanking probe was a 1650 bp PstI-BamHI fragment from an HLA-B27 gene isolated from a subject without $\mathrm{AS}^{16}$ and was also kindly provided by $\mathrm{Dr}$ E Weiss. The probe contains sequences immediately downstream from the poly-A addition signal.

\section{SOUTHERN BLOTTING}

The peripheral lymphocytes from $10 \mathrm{ml}$ of whole EDTA blood were lysed in $90 \mathrm{ml}$ of lysis buffer containing $0.32 \mathrm{M}$ sucrose $(\mathrm{BDH})$, $10 \mathrm{mM}$ TRIS-HCl pH 7.5 (Sigma), $5 \mathrm{mM}$ $\mathrm{MgCl}_{2}(\mathrm{BDH})$, and $1 \%$ (v/v) Triton-X100 (Sigma). The nuclei were pelleted by centrifugation at $2000 \mathrm{~g}$ for 20 minutes and then resuspended in $5 \mathrm{ml} 75 \mathrm{mM} \mathrm{NaCl}(\mathrm{BDH})$, $24 \mathrm{mM}$ EDTA (BDH) $\mathrm{pH} \mathrm{8 \cdot 0.} \mathrm{The} \mathrm{nuclear}$ membranes were lysed by addition of sodium dodecyl sulphate (Sigma) to a final concentration of $0.5 \%$ and $0.2 \mathrm{mg} / \mathrm{ml}$ proteinase $\mathrm{K}$ (Boehringer Mannheim) and incubated at $37^{\circ} \mathrm{C}$ for two to 12 hours. The DNA was then purified by extraction with an equal volume of phenol (BDH) followed by two extractions with chloroform (BDH). The DNA was further purified by addition of $11 \mathrm{ml}$ ethanol (BDH) after addition of sodium acetate $\mathrm{pH} 5 \cdot 2(\mathrm{BDH})$ to a final concentration of $0.3 \mathrm{~mol} / \mathrm{l}$. The precipitated DNA was dissolved in $0.5 \mathrm{ml} \mathrm{TE}$ buffer.

DNA $(10 \mu \mathrm{g})$ was digested to completion with 25-50 units of the restriction enzymes EcoRI, HindIII, or PvuII (BRL/Gibco) as recommended by the manufacturers. The DNA fragments were separated through a $\mathbf{0 . 8 \%}$ agarose (Sigma) gel at $60 \mathrm{~V}$ for 17 to 20 hours in $40 \mathrm{mM}$ TRIS (Sigma), $20 \mathrm{mM}$ acetic acid (BDH), $10 \mathrm{mM}$ EDTA (BDH). The DNA fragments were denatured, neutralised, and transferred to Hybond-N membranes (Amersham, UK) followed by cross linking of the DNA to the nylon membrane by ultraviolet irradiation $(305 \mathrm{~nm})$ for three minutes.

Blots were prehybridised for a minimum of four hours at $65^{\circ} \mathrm{C}$ in $6 \times S S C(900 \mathrm{mM} \mathrm{NaCl}$, $90 \mathrm{mM}$ sodium citrate $\mathrm{pH} 6 \cdot 15), 0 \cdot 01 \% \mathrm{BSA}$ (ICN Immunobiochemicals), $0 \cdot 1 \%(\mathrm{w} / \mathrm{v})$ polyvinylpyrrolidone (Sigma), 0.1\% Ficoll 600 (Pharmacia), 10\% dextran sulphate (Pharmacia), $0 \cdot 1 \%$ sodium dodecyl sulphate, and $0.1 \mathrm{mg} / \mathrm{ml}$ denatured sonicated herring sperm DNA (Sigma). Fresh hybridisation buffer containing $0 \cdot 1 \mathrm{M}$ EDTA was used for overnight hybridisation at $65^{\circ} \mathrm{C}$. Denatured probe labelled with $\left[{ }^{32} \mathrm{P}\right] \mathrm{dCTP}(\mathrm{NEN})$ to a specific activity of at least $10^{8} \mathrm{cpm} / \mu \mathrm{g}$ according to Feinberg and Vogelstein ${ }^{17}$ was also added to the hybridisation buffer at a final concentration of $1-2 \times 10^{6}$ $\mathrm{cpm} / \mathrm{ml}$. After hybridisation the membranes were washed twice in $2 \times \mathrm{SSC} / 0.5 \%$ sodium dodecyl sulphate at $65^{\circ} \mathrm{C}$ for 30 minutes followed by two 30 minute washes in $0.1 \times \mathrm{SSC} /$
$0.5 \%$ sodium dodecyl sulphate at $65^{\circ} \mathrm{C}$. Autoradiography was carried out using screened $x$ ray cassettes at $-70^{\circ} \mathrm{C}$ with Kodak XAR-5 film.

CLONING OF THE HLA-B27 GENE FROM A PATIENT WITH AS

Lymphocytic DNA isolated from a patient with AS heterozygous for the HLA-B27 gene was digested to completion with $E c o$ RI and selected according to size by agarose gel electrophoresis. DNA fragments of about $6.5 \mathrm{~kb}$ containing the HLA-B27 gene were electroeluted and cloned into $\lambda$ gt 10 phages (Amersham, UK). Recombinant phages $\left(7 \times 10^{4}\right)$ were screened with the 3' flanking probe, and one strongly cross hybridising clone was purified. The $6.5 \mathrm{~kb}$ genomic insert was subcloned into pBluescript $\mathrm{SK}+$ (Stratagene) for further characterisation. The DNA sequence was determined with Sequenase after subcloning of suitable DNA fragments into M13 mpl8 or M13 mpl9 bacteriophages.

\section{Results}

RFLP ANALYSIS

Genomic DNA from English and Polish patients with AS and healthy normal subjects was analysed for RFLPs by hybridisation with

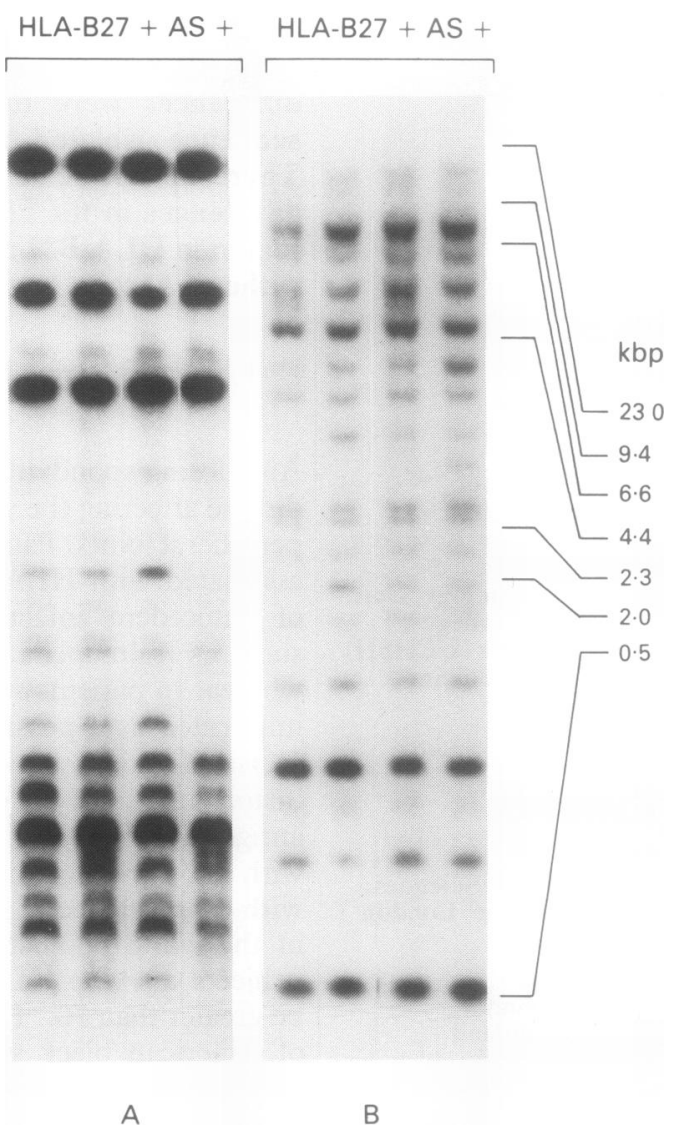

Figure 1 Autoradiograph of PvuII digested genomic DNA from four HLA-B27 positive Polish subjects with AS hybridised with full length $H L A-c D N A$ probe. After hybridisation the blot was washed with $2 \times S S C, 0.1 \%$ sodium dodecyl sulphate $(S D S)$ at $65^{\circ} \mathrm{C}$ and exposed against sodium dodecyl sulphate $(S D S)$ at $65^{\circ} \mathrm{C}$ and exposed against
$x$ ray film for three days $(A)$ after which the stringency of the wash was increased to $0 \cdot 2 \times S S C, 0 \cdot 1 \% S D S$ and the Southern blot was re-exposed to $x$ ray films for seven days $(B)$. 
a number of probes derived from different regions of the HLA-B27 gene or the corresponding cDNA. Hybridisation to Southern blots of EcoRI and HindIII digested DNA showed that the HLA-B27 cDNA probe detected several DNA fragments. Some of these were polymorphic, but none showed any association with the disease (data not shown).

In the light of this a more detailed analysis was performed on Southern blots of PvuII digested DNA. Hybridisation at low stringency of a full length cDNA (fig 1) as well as a $5^{\prime}$ cDNA probe (fig 2) showed about 20 DNA fragments. Most of these are derived from other MHC class I genes which have DNA sequence homology with the HLA-B27 gene. The two probes detect virtually the same fragments, except that the $5^{\prime}$ probe detects no fragments below $2.6 \mathrm{~kb}$. The table lists the frequencies of all fragments detected with the 5 ' cDNA probe. A $14 \mathrm{~kb}$ Pvull fragment was found in $82 \%$ (28/34) of English HLA-B27 positive patients with AS, whereas it appeared in only $29 \%(2 / 7)$ of the English control subjects with HLA-B27. The 14 kb PvuII fragment, however, occurred with the same frequency in the HLA-B27 negative control group as seen among HLA-B27 positive healthy subjects. The $14 \mathrm{~kb}$ PvuII fragment was not an AS susceptibility polymorphism among HLA-B27 positive Polish patients.

The prevalence of the $9.2 \mathrm{~kb} P v u I I$ fragment, described by McDaniel and coworkers, ${ }^{10}$ was low among HLA-B27 positive English and Polish patients with AS (28\% and $15 \%$ respectively). In contrast, this $9.2 \mathrm{~kb}$ fragment was significantly more prevalent in both English and Polish HLA-B27 positive controls $(86 \%$ and $50 \%$ respectively). This suggests a negative association between the disease and the $9.2 \mathrm{~kb}$ fragment among HLA-B27 positive subjects.

The 4.6 and $3.7 \mathrm{~kb}$ fragments were more prevalent in HLA-B27 negative healthy subjects $(70 \%$ and $67 \%$ respectively) than in HLAB27 positive English subjects (35\% and $23 \%$ respectively). The $3.7 \mathrm{~kb}$ fragment was also seen more commonly in healthy subjects $(64 \%)$ than in patients with AS (16\%), irrespective of the presence of the HLA-B27 allele. Among the English patients it was found that the $3.7 \mathrm{~kb}$

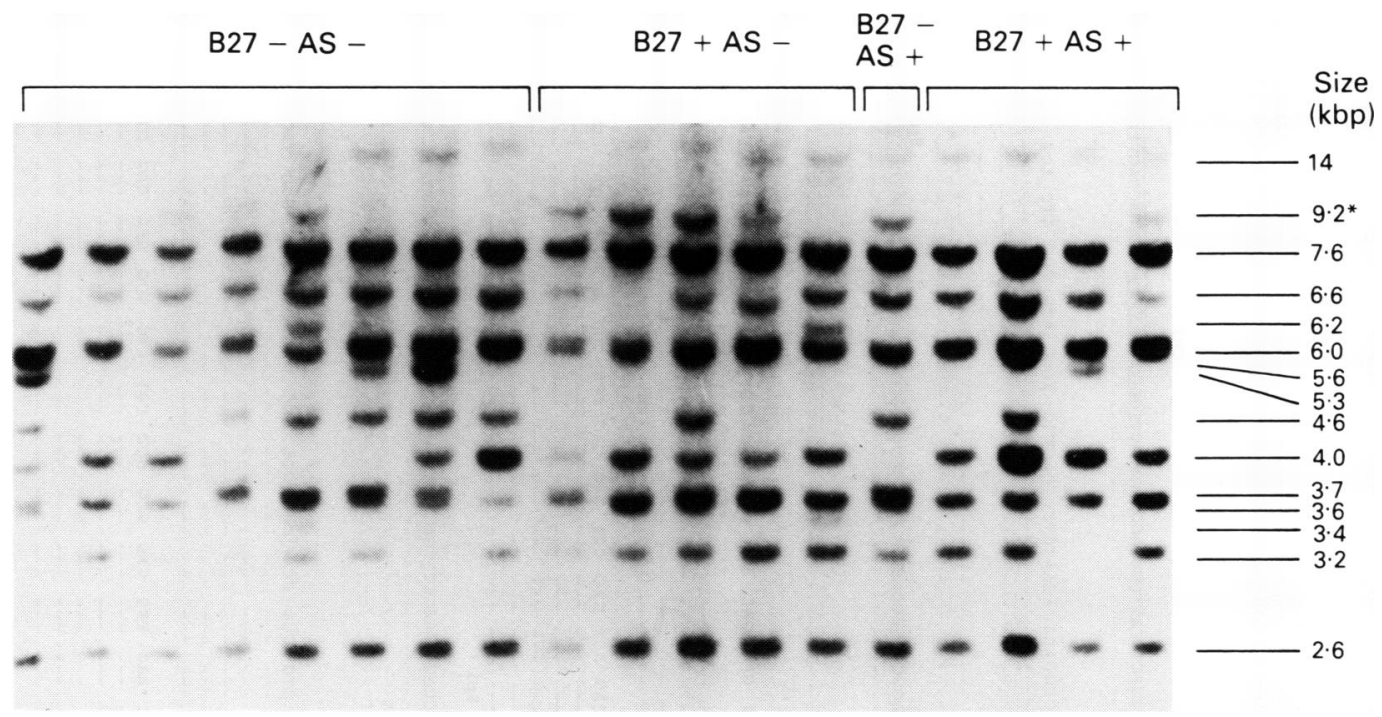

Figure 2 Autoradiograph of PvuII digested genomic DNA from eight HLA-B27 negative healthy subjects, five HLA-B27 positive healthy subjects, one HLA-B27 negative English patient with AS, and four HLA-B27 positive English patients with AS hybridised with the $p B 27-5^{\prime} c D N A$ probe. The $9 \cdot 2 \mathrm{~kb}$ PvulI fragment is indicated with an asterisk.

Prevalence of PvuII fragments hybridising to the $p B 27-5^{\prime}$ cDNA probe in each subset of the English and Polish groups. The $9.2 \mathrm{~kb}$ PvuII fragment is indicated with an asterisk. The percentage of patients with each fragment is shown

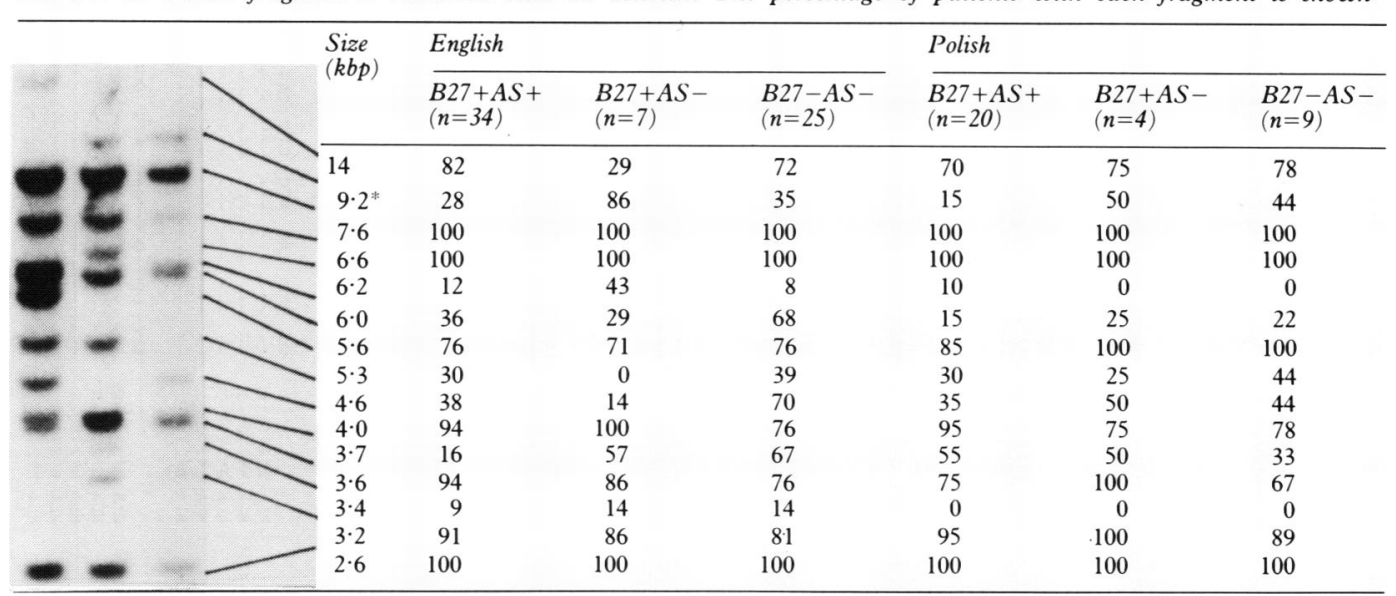




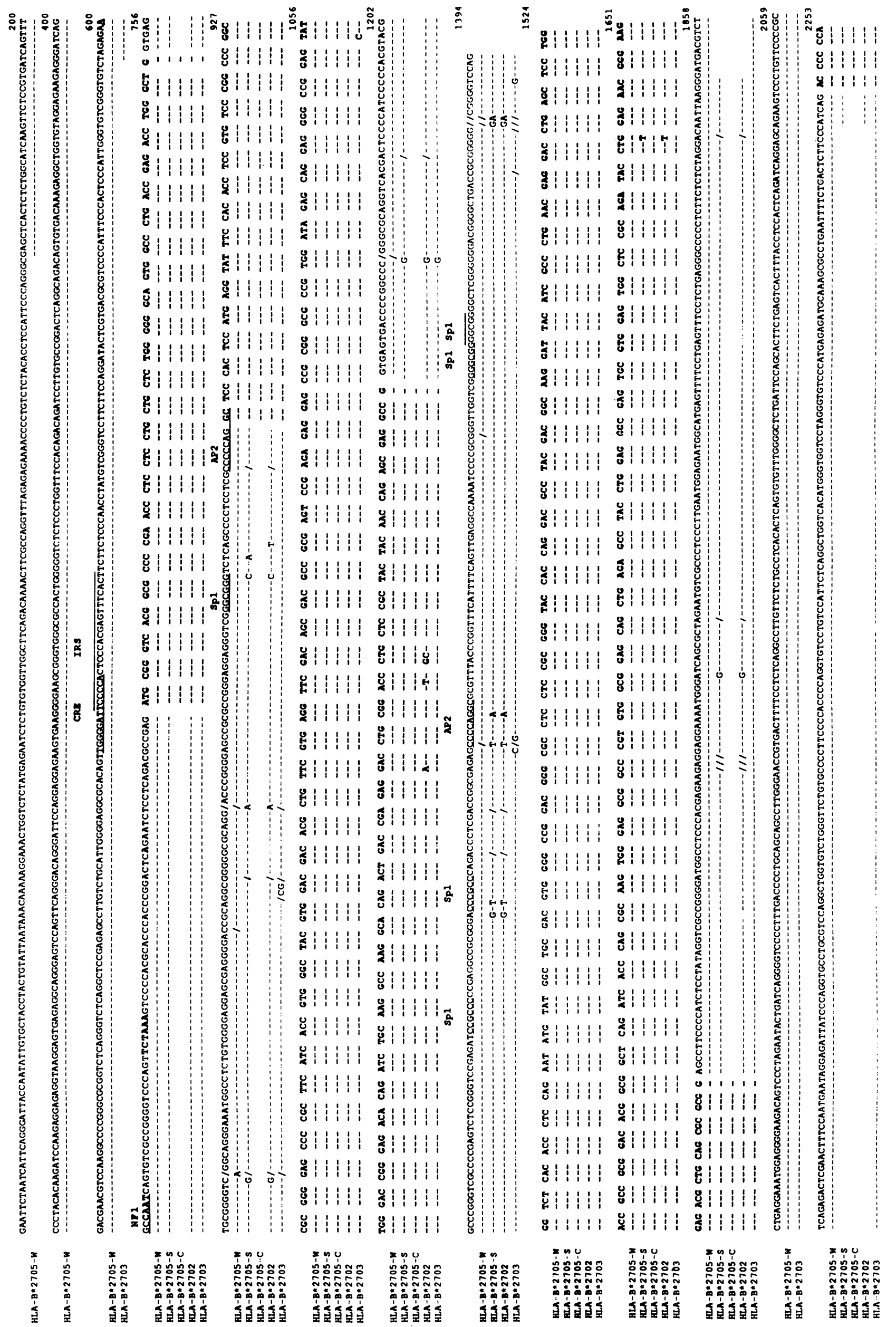

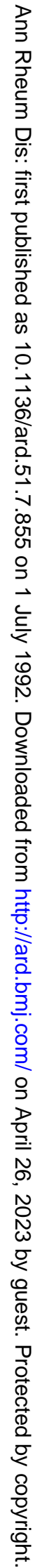




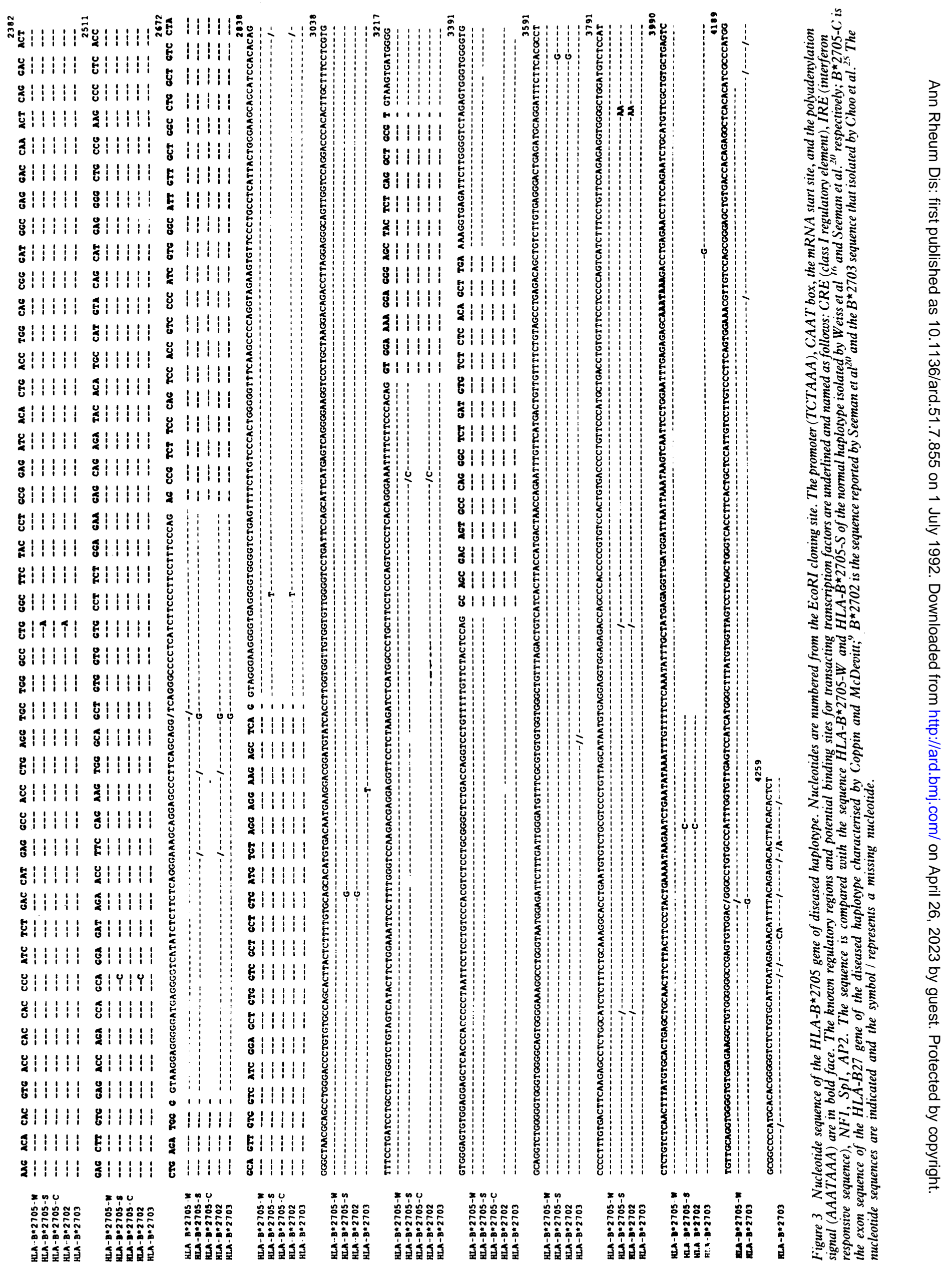




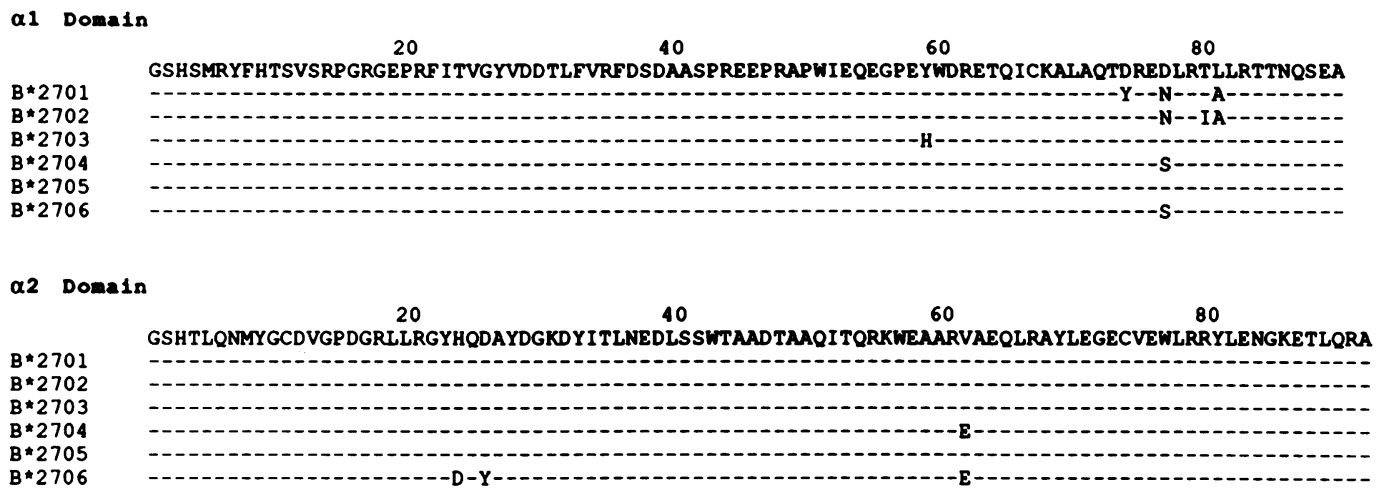

Figure 4 Comparison of the deduced amino acid sequence of the $\alpha 1$ and $\alpha 2$ domains of the HLA-B27 gene presented here with those of other HLA-B27 subtypes. The amino acid sequences were compiled from Rojo et al ${ }^{26}\left(B^{\star} 2701\right)$, Seeman et al 20 $\left(B^{\star} 2702\right)$, Choo et al,$^{25}\left(B^{\star} 2703\right)$, Rojo et al ${ }^{27}\left(B^{\star} 2704\right)$, Weiss et al ${ }^{16}\left(B^{\star} 2705\right)$, and Vega et al ${ }^{28}\left(B^{\star} 2706\right)$.

PvuII fragment was seen more commonly among patients with uveitis $(36 \%)$ than in those without (5\%).

Hybridisation of the Southern blots of PvuII digested DNA with the $3^{\prime}$ cDNA and the $3^{\prime}$ flanking probe showed a more simple hybridisation fragment pattern detecting few polymorphic fragments. None of these, however, showed any particular association with the disease in either of the two groups studied.

\section{DNA SEQUENCE OF AN HLA-B27 ALLELE}

As the RFLP analysis did not show any striking disease association the HLA-B27 allele from a patient with AS was cloned and sequenced to identify possible differences between it and that of a healthy subject. To ensure that the HLAB27 allele isolated indeed would be associated with the disease, a partial genomic library of DNA isolated from a patient with AS carrying only one copy of the HLA-B27 allele was prepared. As characterisation of cloned HLA-B genes had previously shown that the HLA-B gene was contained on a $6.5 \mathrm{~kb} E c o R I$ fragment, ${ }^{16}$ DNA fragments of about $6.5 \mathrm{~kb}$ were cloned into $\lambda$ gt 10 phages. Screening with $3^{\prime}$ flanking probe identified one HLA-B27 clone. Figure 3 shows the DNA sequence of $4259 \mathrm{bp}$ of this clone. DNA sequence comparison between the HLA-B27 gene from normal subjects and the one isolated here from a patient with AS showed no striking differences either in the promoter and regulatory region or in the region containing the structural gene. In particular exons V, VI, and VII were identical. Indeed, few nucleotide differences could be detected in the sequence of the gene isolated by us and that isolated by Weiss et al ${ }^{16}$ from a nondiseased subject. None of the nucleotide differences changed the amino acid sequence. Thus when translated into an amino acid sequence the HLA-B27 gene we cloned encoded a protein identical to that encoded by the HLA-B ${ }^{\star} 2705$ allele (fig 4).

\section{Discussion}

More than $95 \%$ of white patients with AS are positive for the MHC class I antigen HLA-B27, but only about $20 \%$ of all HLA-B27 positive subjects are likely to develop some stigmata of the disease, though the incidence seems to be higher in families with a history of AS. ${ }^{18}$ This might be due to the influence of other genetic as well as environmental factors on the pathology of the disease. As RFLP analysis has proved useful in associating particular DNA polymorphisms with diseases ${ }^{19}$ an extensive search for RFLPs preferentially associated with AS alone or together with HLA-B27 was carried out. McDaniel and coworkers described a $9 \cdot 2$ kb PvuII DNA fragment which was detected with an HLA-B27 cDNA probe, ${ }^{10}$ and in a study of patients with AS from Alabama (USA) it was found to be present in $73 \%$ of HLA-B27 positive patients with spondylitis compared with only $27 \%$ of the healthy subjects with HLA-B27. The $9 \cdot 2 \mathrm{~kb}$ Pvull gene seems to increase the relative risk from 90 (for HLA-B27 alone) to a relative risk of 297 when both markers are present. ${ }^{10}$ The $9 \cdot 2 \mathrm{~kb}$ PvuII fragment was later identified as a polymorphism of the HLA-A3 or the HLA-A9 gene, ${ }^{12}$ suggesting the existence of either a second MHC linked AS susceptibility gene, a disease gene different from HLA-B27 but in linkage disequilibrium with the HLA-B27 gene, or a particular allelic form of the HLA-B27 gene associated with AS.

RFLP studies of patients with AS in Baltimore, ${ }^{12}$ Minnesota and Texas, ${ }^{11}$ and in Germany, ${ }^{13}$ however, have all failed to confirm the preferential association of the $9 \cdot 2 \mathrm{~kb}$ PvuII fragment and AS in HLA-B27 positive subjects as reported by McDaniel et al. ${ }^{10}$ Indeed none of these RFLPs identified by MHC class I polymorphisms preferentially associated with AS in HLA-B27 positive subjects. We analysed patients with ankylosing spondylitis from two geographically isolated, but in themselves homogeneous, groups from England and Poland. We found no increase in the prevalence of the haplotype HLA-A3/A9, HLA-B27 among patients with spondylitis compared with normal subjects. We did find, however, a preferential association between AS and a $14 \mathrm{~kb}$ PvuII fragment among HLA-B27 positive patients compared with HLA-B27 healthy subjects in the English group (but not in the Polish group), though this failed to reach statistical significance when corrected for the number of fragments examined. None of the 
other studies ${ }^{10-13}$ reported a similar association. Only seven healthy subjects in our English control group had the HLA-B27 class I allele so this preferential association might not persist if a larger control group were to be studied. There is insufficient tissue typing data of our patient group to identify the MHC class I gene containing the $14 \mathrm{~kb}$ polymorphism. In addition, $4.6 \mathrm{~kb}$ and $3.7 \mathrm{~kb}$ polymorphic fragments were found which, in the English control group, were more prevalent in HLA-B27 negative subjects than in those who were HLA-B27 positive, and the $3.7 \mathrm{~kb}$ fragment was more prevalent in healthy subjects than in patients with AS irrespective of whether the subjects were positive for HLA-B27 or not. This seems to be a negative correlation among English patients with AS, but this association was not seen in the Polish group.

The conflicting results might be due to genetic differences between the groups studied. The HLA-A3/A9 allele might be linked with the disease allele in the Alabama group studied by McDaniel et $a l,{ }^{10}$ whereas such a linkage might not exist in the other groups with AS. Likewise, the $14 \mathrm{~kb}$ Pvull fragment, which appears to be preferentially linked together with HLA-B27 to AS in the English group as reported here, but absent in the other group studied, might reflect the genetic diversity between different populations. This implies that no additional MHC class I gene is involved in the pathology of AS. If the HLA-B27 gene is not the disease gene itself or if additional MHC encoded susceptibility genes exist then they must be very close to the HLA-B27 allele.

The discrepancy between the number of people carrying HLA-B27 and those developing AS could be explained if there existed particular susceptibility alleles of HLA-B27 which cannot be identified by restriction fragment analysis. We sequenced the entire structural HLA-B $\star 2705$ gene from a patient with AS. Our results show that the translated amino acid sequence is identical with the sequence of an HLA-B $\star 2705$ antigen isolated from a healthy person. ${ }^{16} 20$ This is in complete agreement with Coppin and McDevitt, ${ }^{9}$ who found no differences between the translated sequence of exon II, III, and IV encoding the extracellular portion of the MHC class I antigen in HLA-B27 proteins from patients with AS and healthy subjects. Furthermore, our DNA sequence shows that the promoter and regulatory region of the HLAB27 gene isolated by us is virtually identical to the non-diseased gene characterised by Weiss $e t$ $a l .{ }^{16}$ This eliminates the possibility that the pathology of AS might be due to altered expression of the HLA-B27 antigen. We found very few nucleotide differences between the HLA-B ${ }^{\star} 2705$ gene isolated by us and the nucleotide sequence of a similar allele from a normal subject cloned and sequenced by Weiss et $a{ }^{16}$ and Seeman et al. ${ }^{20}$ We noted some nucleotide differences in exon II and IV but none which would result in amino acid differences. We also found sequence differences within intron I and II when compared with previously published sequences for non-diseased HLA-B ${ }^{\star} 2705$ alleles. ${ }^{1620}$ Interestingly, some of these differences create or destroy potential binding sequences for the transcription factors SP1 or AP2. It has not been shown that such binding sites are used in regulation of the transcription, however.

The absence of any differences between the coding sequence of the HLA-B27 genes from patients and healthy subjects does not eliminate a direct role for HLA-B27 in the pathogenesis of the disease through its function as restriction element for antigen presentation to cytotoxic $\mathrm{T}$ cells. $^{21}$ Many organ specific autoimmune diseases, like insulin dependent diabetes mellitus and Hashimoto's disease, are characterised by a cellular as well as a humoral immune response. Ankylosing spondylitis might well be initiated by an infection of klebsiella or related bacteria. ${ }^{22}$ The fact that the concordance rate for AS in identical twins is well below $50 \%$ clearly suggests the involvement of an environmental factor in a genetically susceptible host ${ }^{23}$ who may have more than one susceptibility gene. Family studies suggest a possible role for a second susceptibility gene, not necessarily located in the MHC region. Such a second susceptibility gene could code for a self protein sharing a $T$ cell epitope with a bacterial protein, which might have a restricted tissue distribution, and this might account for the tissue specificity of the disease. A shared T cell epitope would then only be presented by HLA-B27 or a related MHC class I antigen with a nearly identical antigen binding groove. ${ }^{24}$

Clearly, further studies are required to resolve the problem of the association of HLAB27 with AS.

We thank Drs G. Melmer and P Delves for critical comments in preparation of this manuscript. Supported by grants from the trustees of the Middlesex Hospital, London.

1 Toivanen A, Granfors K, Lahesmaa-Rantala R, Leino R Stahlberg T, Vuento $R$. Pathogenesis of yersinia-triggered reactive arthritis: immunological, microbiological and clinical aspects. Immunol Rev 1985; 86: 47-70.

2 Ebringer R, Cooke D, Cawdell O R, Cowling P, Ebringer A Ankylosing spondylitis: klebsiella and HLA-B27. Rheumatol Rehabil 1977; 16: 190-6.

3 Ebringer A. The relationship between klebsiella infection and ankylosing spondylitis. In: Rooney $\mathrm{P} J$, ed. The gut and rheumatic disease. Balliere's Clin Rheumatol 1989; 3: 321-38.

4 Brewerton D A, Caffrey M, Hart F D, James D C O Nicholls A, Sturrock R D. Ankylosing spondylitis and HLA-B27. Lancet 1973; i: 904-7.

5 Schlosstein L, Terasaki P I, Bluestone R, Pearson C M. High association of an HL-A antigen, W27, with ankylosing spondylitis. N Engl f Med 1973; 288: 704-6.

6 Tiwari J L, Terasaki P I. Ankylosing spondylitis. HLA and disease association. Berlin: Springer, 1985: 85-100.

7 Keat A. Is spondylitis caused by klebsiella? Immunol Today 1986; 7: 144-9.

8 Ebringer A. The cross-tolerance hypothesis, HLA B27 and ankylosing spondylitis. Br $\mathcal{F}$ Rheumatol 1983; 22 (suppl 2): $53-66$

9 Coppin H L, McDevitt H O. Absence of polymorphism between HLA-B27 genomic exon sequences isolated from normal donors and ankylosing spondylitis patients. f Immunol 1986; 137: 2168-72.

10 McDaniel D O, Acton R T, Barger B O, Koopman W J Reveille J D. Association of a $9 \cdot 2$ kilobase Pvu II class major histocompatibility complex restriction fragmen length polymorphism with ankylosing spondylitis. Arthritis Rheum 1987; 30: 894-900.

11 Durant J P, Taurog J D. Association between ankylosing spondylitis and a $9 \cdot 2 \mathrm{~kb}$ Pvu II class I HLA DNA restriction fragment: a reassessment. $\mathcal{I}$ Rheumatol 1988 ; 15 . 1119-22.

12 Ahearn J M, Calomiris J J, Wigley F M, Jabs D A, Bias W B Hochberg M C. Characterization of the class I HLA $9 \cdot 2 \mathrm{~kb}$ Pvu II restriction fragment length polymorphism. Linkage to HLA-A and lack

13 Weiss E H, Bloemer K, Doerner C, et al. Molecular biology 
of the HLA-B27 locus. $B r \mathcal{F}$ Rheumatol 1988; 27 (suppI 2): 12-18.

14 Bennett P H, Burch T A. New York symposium on population studies in the rheumatic diseases: new diagnostic criteria. Bull Rheum Dis 1967; 32: 354-63

15 Szoets H, Riethmüller G, Weiss E H, Meo T. Complete sequence of HLA-B27 cDNA identified through the characterization of structural markers unique to the HLA A, -B, and -C allelic series. Proc Natl Acad Sci USA 1986; 83: $1428-32$.

16 Weiss E H, Kuon W, Doerner C, Lang M, Riethmüller G. Organization, sequence of expression of the HLA-B27 gene: a molecular approach to analyze HLA and disease gene: a molecular approach to analyze HLA and

17 Feinberg A P, Vogelstein B. A technique for radiolabelling DNA restriction endonuclease fragments to high specific activity. Anal Biochem 1983; 132: 6-13.

18 Woodrow J C, Nichol F E, Whitehouse G H. Genetic studies in ankylosing spondylitis. Br $\mathcal{F}$ Rheumatol 1983; 22 (suppl 2): $12-17$.

19 Tsui L C, Bughwald M, Barker D, et al. Cystic fibrosis locus defined by genetically linked polymorphic DNA markers. Science 1985; 230: 1054-7.

20 Seeman G H A, Rein R S, Brown C S, Ploegh H L. Gene conversion-like mechanisms may generate polymorphism conversion-like mechanisms may generate polymor
in human class I genes. $E M B O$ f $1986 ; 5: 547-52$

21 Benjamin R Parham P. Guilt by association: HLA-B27 and ankylosing spondylitis. Immunol Today 1990; 11: 137-42.
22 Trull A, Ebringer A, Panayi G, Ebringer R, James D C O. HLA-B27 and the immune response to enterobacterial antigens in ankylosing spondylitis. Clin Exp Immunol 1984; 55: 74-80.

23 Eastmond C J, Woodrow J C. Discordance for ankylosing spondylitis in monozygotic twins. Ann Rheum Dis 1977; 36: $360-4$.

24 Ewing C, Ebringer R, Tribbick G, Geysen H M. Antibody activity in ankylosing spondylitis sera to sites on HLAB27.1 at the MHC groove region (within sequence 65-85), and to a Klebsiella pneumoniae nitrogenase reductase peptide (within sequence 181-199). $\mathcal{F}$ Exp Med 1990; 171: peptide

25 Choo S Y, St John T, Orr H T, Hansen J A. Molecular analysis of the variant alloantigen HLA-B27d (HLA-B ${ }^{2} 2703$ ) identifies a unique single amino acid substitution. Hum Immunol 1988; 21: 209-19.

26 Rojo S, Aparicio P, Choo S Y, Hansen J, Lopez de Castro J A. Structural analysis of an HLA-B27 population variant, B27f. I Immunol 1987; 139: 831-6.

27 Rojo S, Aparicio P, Hansen J A, Choo S Y, Lopez de Castro J A. Structural analysis of an HLA-B27 functional variant, B27d, detected in American blacks. F Immunol 1987; 139: $3396-401$.

28 Vega M A, Bragado R, Ivanyi P, Palaez J L, Lopez de Castro J A. Molecular analysis of a functional subtype of HLA-B7. A possible evolutionary pathway for HLA-B27 polyA possible evolutionary pathway for
morphism. F Immunol 1986; 137: 3557-65. 


\section{Food intolerance in rheumatoid arthritis}

Sir: We read with interest the two papers by Drs van de Laar and van der Korst on food intolerance in rheumatoid arthritis (RA). ${ }^{12}$ It appears from this extensive but short study of patients with seropositive RA that rheumatoid disease in a small subgroup is sensitive to dietary manipulation. Identification of these patients is, however, a problem.

We have previously shown that significant gut abnormalities are associated with raised levels of IgA rheumatoid factor (RF) and dietary protein specific IgG in patients with RA and suggested that these changes might identify patients who would respond to dietary manipulation. ${ }^{3}$

Gendre and colleagues have described villous atrophy and other histological abnormalities of the small intestine in patients with RA. ${ }^{4}$ These changes were more significant among IgM RF negative patients (who are often IgA RF positive).

In the recent study the number of patients examined histologically was small, therefore a firm conclusion cannot be reached. Moreover, it is likely that by excluding IgM RF negative patients with RA some food intolerant patients might have been missed. Furthermore, investigation of intestinal structure and function in RA is severely hampered by the damaging effects of non-steroidal anti-inflammatory drugs, which are so often used by patients with RA. Thus a fundamental question remains extremely difficult to answer-that is, whether gut abnormalities and any of the manifestations associated with these abnormalities in patients with RA are secondary to the disease process and its treatment or are of primary pathogenic significance. CLIONA O'FARRELLY DLPartment of Immunology St fames's Hospital Dublin 8

Correspondence to: Dr O'Farrelly.

1 van de Laar M A F J, van der Korst J K. Food intolerance in rheumatoid arthritis. I. A double blind, controlled trial of the clinical effects of elimination of milk allergens and azo dyes. Ann Rheum Dis 1992; 51: 298-302.

2 van de Laar M A F J, Aalbers M, Bruins F G van Dinther-Janssen A C H M, van der Kors $J \mathbf{K}$, Meijer C J L M. Food intolerance in rheumatoid arthritis. II. Clinical and histological aspects. Ann Rheum Dis 1992; 51: 303-6.

3 O'Farrelly C, Marten D, Melcher D, et al. Association between villous atrophy in rheu- matoid arthritis, rheumatoid tactor and gliadin-specific IgG Lancet 1988; ii: 819-23. 4 Gendre J P, Luboinski J, Prier A, Camus J P, le Quintrec $Y$. Anomalies de la muqueuse Quintrec Gastroenterol Clin Biol 1982; 6: 772-5.

AUTHORS' REPLY We appreciate the interest of Drs Abuzakouk and O'Farrelly in our papers on food intolerance in rheumatoid arthritis $(\mathrm{RA}) .^{12}$ In the first paper the existence of intolerance for food in a minority of patients was suggested and in the second paper the patients with food intolerance were described in more detail. We hoped that the clinical, immunological, and histological investigations in these patients might provide some clues to the problem of how to identify food intolerant patients. However, possibly because of the limited number of patients, such predicting parameters were not found. As suggested by Drs Abuzakouk and O'Farrelly IgA rheumatoid factor (RF) might by such a parameter-this possibility was not considered in our paper. We studied several dietary protein specific IgGs, however, but a discriminatory high level of these antibodies was not found.

Histological abnormalities of the small intestine are of particular interest in connection with food intolerance in RA. ${ }^{4-6}$ However, as this needs an invasive technique the availability of material for study is limited. Moreover, several other factors, such as the effect of non-steroidal anti-inflammatory drugs, do influence intestinal histology.

The existence of food intolerance in RF negative RA might indeed exceed that in positive disease. In these studies, however, we preferred to study the more homogeneous type of RA-namely, RF positive cases.

We should mention that we are at present studying the identification of food intolerant patients with RA. In this study many of the suggestions made by Drs Abuzakouk and O'Farrelly are included.

MARTIN A F J VAN DE LAAR JAN K VAN DER KORST
Vakgroep Reumatologie Twente Ziekenhuizen: Twenteborg, Almelo en Medisch Spectrum Twente PO Bnschede 7600 SZ Almelo The Netherlands

I van de Laar M A F J, van der Korst J K. Food intolerance in rheumatoid arthritis. I. A double blind, controlled trial of the clinical effects of elimination of milk allergens and azo dyes. $A$ nn Rheum Dis 1992; 51: 298-302.

2 van de Lar M A F J, Aalbers M, Bruins F G, van Dinther-Janssen A C H M, van der Korst J K, Meijer C J L M. Food intolerance in heumatoid arthritis. II. Clinical and histological aspects. Ann Rheum Dis 1992; 51: $303-6$.

3 van de Laar M A F J, Aalbers M, van der Kors $J$ K. Radioallergosorbent tests to foods in $K$. Radid alleroso rheumatid arthris. ed. Rheumatoid arthitis and food allergy Amsterdam: Thesis Publishers, 1991: 81-91.

4 Marcolongo R, Bageli P F, Montagnami M Gastrointestinal involvement in rheumatoid arthritis: a biopsy study. $\mathcal{F}$ Rheumatol 1979 6: 426-40.

5 Doube A, Collins A J. Is the gut intrinsically abnormal in rheumatoid arthritis. Ann Rheum Dis 1988; 47: 617-9.

6 van de Laar M A F J, van der Korst J K. Rheumatoid arthritis, food and allergy. Semin Arthritis Rheum 1991; 21: 12-23.

\section{Correction}

Ankylosing spondylitis and HLA-B27: restriction fragment length polymorphism and sequencing of an HLA-B27 allele from a patient with ankylosing spondylitis

In the paper by $C M$ Higgins, $T$ Lund, $M E$ Shipley, et al (Ann Rheum Dis 1992; 51 : 855-62) we regret that fig 1 was incorrectly reproduced. The correct version of this figure is shown below.

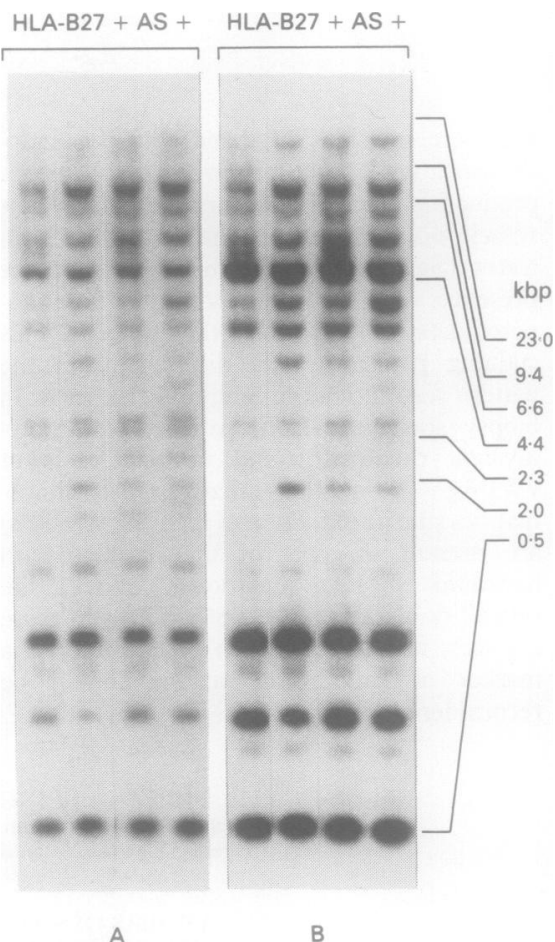

